\title{
ECOLOGICAL ASSESSMENT OF THE SAN RIVER WATER QUALITY ON THE AREA OF THE SAN VALLEY LANDSCAPE PARK
}

\author{
Teresa Noga', Jadwiga Stanek-Tarkowska², Anita Pajączek², Natalia Kochman³ ${ }^{3}$ Łukasz Peszek³ \\ 1 Department of Biological Foundations of Agriculture and Environmental Education, Faculty of Biology and \\ Agriculture, University of Rzeszów, Ćwiklińskiej 2, 35-601 Rzeszów, Poland, e-mail: teresa.noga@interia.pl \\ 2 Department of Soil Studies, Environmental Chemistry and Hydrology, Faculty of Biology and Agriculture, \\ University of Rzeszów, Ćwiklińskiej 2, 35-601 Rzeszów, Poland, e-mail: jagodastanek@wp.pl; chuanita66@ \\ poczta.fm \\ ${ }^{3}$ International Doctoral Studies in Natural Sciences, Faculty of Biology and Agriculture, University of Rzeszów, \\ Ćwiklińskiej 2, 35-601 Rzeszów, Poland, e-mail: lukaspeszek@gmail.com; kochman_natalia@wp.pl
}

Received: 2014.05.11

Accepted: 2014.08.05

Published: 2014.10.07

\begin{abstract}
Water of the San River was characterized by good and high ecological status and high diatom richness. During four studied seasons at two sites 353 diatom taxa were identified in total, from which the most numerous were Achnathidium pyrenaicum (Hust.) Kobayasi and Achnanthidium minutissimum (Kütz.) Czarnecki var. minutissimum. Water of the San River, was characterized by high and good water quality (II and I class) in all seasons and at both studied sites.
\end{abstract}

Keywords: Diatoms, ecological status, diatomaceous indices IPS,GDI,TDI.

\section{INTRODUCTION}

Diatoms are a specialized group of organisms, occurring in most aquatic ecosystems or constantly moist ones. Therefore, they are always available to collect. In unfavorable conditions (including drying, freezing) they can survive in a vegetative form. Species diversity is important in assessing the environmental status of various aquatic ecosystems and is expressed in the lists of species, their autecology, number of individuals, etc. In assessment of purity of rivers it is important to distinc sensitive species, tolerant, resistant, with quantitative shares. Diatoms occurring in different biotopes can be accurately determined and counted and their communities can be compared in different types of environments, thus, they are an excellent material for the study of species diversity [Siemińska 1964, Rakowska 2001]. Monitoring studies with the use of diatoms to assess the quality of water are conducted in many European countries as well as in Poland [Prygiel, Coste 1993, Kelly, Whitton 1995, Kelly et al. 1995, Kwandrans et al. 1999, Eloranta 1999, Kawecka,
Kwandrans 2000, Bogaczewicz-Adamczak et al. 2001, Rakowska 2001, Kwandrans 2002, Prygiel 2002, Bogaczewicz-Adamczak, Dziengo 2003, Kelly 2003, Kelly et al. 2008, Żelazowski et al. 2004, Dumnicka et al. 2006, Rakowska, Szczepocka 2011]. For this purpose a computer software OMNIDIA [Lecointe et al. 1993] was prepared, which includes taxonomic and ecological databases, together with indicative values and sensitivity degrees of individual diatom taxa.

Regular studies which aim to investigate the diversity of diatoms in the flowing water, together with an assessment of water quality have been carried out in the Podkarpacie Province only since 2007 [Noga, Siry 2010, Tambor, Noga 2011, Noga 2012, Pajączek et al. 2012, ŻelaznaWieczorek 2012, Noga et al. 2013a,b,c,d]. Previously, individual studies were carried out only in the upper reach of the San River in connection with the massive growth of Didymosphenia geminata below the reservoirs of "Solina" and "Myczkowce" dams [Kawecka, Sanecki 2003].

The aim of this work is to recognize the diatom species diversity and the ecological water 
quality of the upper section of the area of the San River on the territory of the San Valley Landscape Park using three diatomaceous indices (IPS, GDI, TDI) calculated with the computer software OMNIDIA.

\section{STUDY AREA}

The San River with a $443.4 \mathrm{~km}$ length is the largest and has one of the richest of water among the Carpathian rivers.

The upper San basin is one of the most valuable area in Poland and includes more than $90-\mathrm{km}$ stretch of the river from the source to the reservoir at Solina dam. It is a highland river for the first 50 kilometers, in the further part it is a mountain river. The San River Valley is characterized by a shallow and wide riverbed, steep shores and therefore the Carpathian flysch, which is typical for this region, can be observed. Numerous rapids are in the riverbed especially on the section between Stuposiany and Rajskie [Kukuła 2002, Sieradzki 2002, Szlak wodny „Błękitny San” 2005].

The study sites were located in Procisne near the bridge on the San River on the national road No. 896 and in Sękowiec also near the bridge over the San River (Figure 1). Detailed description of the positions is presented in Table 1 .

\section{MATERIAL AND METHODS}

The material for this study was collected four times from October 2010 to September 2011 from all available habitats (stones, slit and aquatic macrophytes) in the San River on the San Valley Landscape Park area. $\mathrm{pH}$, conductivity and water temperature were measured directly in the field. Samples of water for chemical analysis were taken during the last study season (September 2011).

The collected material was preserved in a $4 \%$ solution of formalin. In order to obtain pure valves of diatoms a part of the obtained material was subjected to maceration in a mixture of sulphuric acid and potassium dichromate in a ratio $3: 1$, and next it was rinsed in a centrifuge (at $2500 \mathrm{rpm}$ ). The diatoms were mounted in permanent diatom slides with synthetic resin - PLEURAX (refractive index 1.75). The material was prepared according to the methods applied by Kawecka [2012].

Diatoms were identified using the Nikon 80i light microscope, according to keys: Krammer, Lange-Bertalot [1986, 1988, 1991a,b], Lange-Bertalot [2001], Krammer [2000, 2002, 2003], Hofmann et al. [2011].

Diatoms were identified and counted using DIC (Differential Interference Contrast) under a Nikon ECLIPSE 80i microscope. The ultrastructure was examined under a Hitachi S-4700 electron microscope in the laboratory of Field Emis-

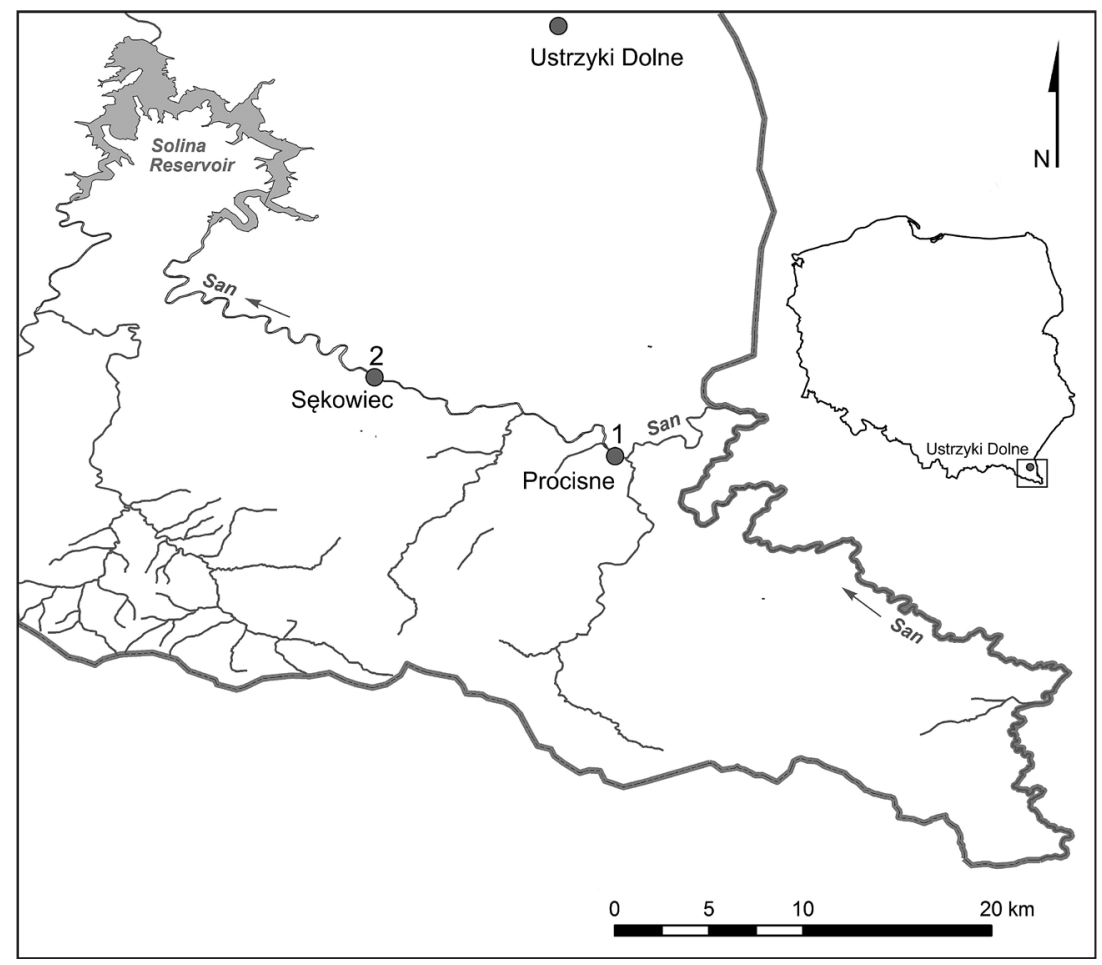

Figure 1. Location of the study sites 
sion Microscopy, Scanning Electron Microscopy and Microanalysis (Institute of Geological Sciences of the Jagiellonian University in Cracow). Chemical analysis of water was carried out in the Departmental Laboratory of Analysis of Wholesomeness of Environment and Materials of Agricultural Origin, by means of a liquid chromatography apparatus PeakNet Dionex 2001-2006, version 6.80 .

Species composition in the samples was determined through counting specimens on randomly selected fields of view under a light microscope. The number of valves counted was 400 . Species with a content above $5 \%$ in a given diatom assemblage were defined as abundant.

Ecological diatoms classification was presented according to the Van Dam et al. [1994] list. The following indicators were used: $\mathrm{pH}$, saprobity and trophic state.

Biological water quality assessment was performed using OMNIDIA software [Lecointe et al. 1993], version 4.2. This also contains ecological and taxonomic data [Prygiel, Coste 1993]. Results of the analyses were presented applying the chosen diatomic indices, for which a range of ecological classes of water quality and the eco- logical status conforming to them was outlined by mutual agreement [Dumnicka et al. 2006]:

\begin{tabular}{|c|c|c|c|c|c|}
\hline $\begin{array}{c}\text { Water } \\
\text { Quality } \\
\text { Clas }^{*}\end{array}$ & $\begin{array}{c}\text { Ecological } \\
\text { status }\end{array}$ & IPS & GDI & TDI & Trophic status \\
\hline I & high & $>17$ & $>17$ & $<35$ & oligotrophic \\
\hline II & good & $15-17$ & $14-17$ & $35-50$ & $\begin{array}{c}\text { oligo- } \\
\text { mesotrophic }\end{array}$ \\
\hline III & moderate & $12-15$ & $11-14$ & $50-60$ & mesotrophic \\
\hline IV & poor & $8-12$ & $8-11$ & $60-75$ & eutrophic \\
\hline $\mathrm{V}$ & bad & $<8$ & $<8$ & $>75$ & hypertrophic \\
\hline
\end{tabular}

* According to the Decree of the Minister of the Environment from 9 Nov. 2011 (Dz. U. No 257, pos. 1545).

Indices of organic pollution: the SPI - Specific Pollution Sensitivity Index [CEMAGREF 1982] and the GDI - Generic Diatom Index based on genera are scaled from 1 to 20 (when water quality increases there is an increase in indicator value). The TDI - Trophic Diatom Index is scaled from 1 to 100 (the higher the value, the bigger trophy of water). The percentage of participation of species characteristic for organic pollution (PT) must be taken into account in interpretation of the TDI index. There is a possibility of organic pollution if PT values are above

Table 1. Characteristic of the investigated sites, designated on the San River, including the dominant, endangered and rare species

\begin{tabular}{|c|c|c|}
\hline Site & PROCISNE & SĘKOWIEC \\
\hline Width [m] & about 18 & about 20 \\
\hline Depth [m] & $0.2-0.5$ & $0.2-0.7$ \\
\hline Insolation & Medium & Low \\
\hline Bottom & Stony, large boulders in the center of riverbed & $\begin{array}{l}\text { Stony, rock outcrops of Carpatian flysh in } \\
\text { riverbed }\end{array}$ \\
\hline Dominant species [>5\%] & $\begin{array}{l}\text { Achnanthidium pyrenaicum, A. minutissimum var. } \\
\text { minutissimum, A. catenatum, Encyonopsis minuta, } \\
\text { E. subminuta }\end{array}$ & $\begin{array}{l}\text { Achnanthidium pyrenaicum, } A \text {. subatomus, } \\
\text { A. minutissimum var. minutissimum, Denticula } \\
\text { tenuis, Fragilaria perminuta, Encyonopsis } \\
\text { subminuta }\end{array}$ \\
\hline \multicolumn{3}{|c|}{ Endangered and rare species (accoding to Siemińska et al. 2006) } \\
\hline $\begin{array}{l}\text { Endangered } \\
{[\mathrm{E}]}\end{array}$ & $\begin{array}{l}\text { Encyonema gauemanni, Fallacia lenzii, } \\
\text { Neidium alpinum, Pinnularia subruperstris, } \\
\text { Sellaphora pseudopupula }\end{array}$ & $\begin{array}{l}\text { Fallacia lenzii, Pinnularia schonfelderii, } \\
\text { P. subruperstris, P. viridiformis, Sellaphora } \\
\text { pseudopupula }\end{array}$ \\
\hline $\begin{array}{l}\text { Vulnerable } \\
{[\mathrm{V}]}\end{array}$ & $\begin{array}{l}\text { Fragilaria tenera, Gomphonema sarcophagus, } \\
\text { Navicula splendicula, Pinnularia microstauron, } \\
\text { Psammothidium laueunburgianum, } \\
\text { P. subatomoides, Sellaphora bacillum }\end{array}$ & $\begin{array}{l}\text { Fragilaria nanana, F. tenera, Gomphonema } \\
\text { sarcophagus, Navicula splendicula, } \\
\text { Psammothidim laueunburgianum, } \\
\text { P. subatomoides, Sellaphora bacillum }\end{array}$ \\
\hline $\begin{array}{l}\text { Rare } \\
{[R]}\end{array}$ & $\begin{array}{l}\text { Achnanthes coarctata, Amphora cimbrica, } \\
\text { Amphipleura pellucida, C. lancettula, C. molaris, } \\
\text { C. schumaniana, Cymbella helvetica, } \\
\text { C. lanceolata, C. proxima, Diploneis pseudoovalis, } \\
\text { Fallacia subhamulata, Fragilaria brevistriata, } \\
\text { Geissleria deccusis, Hippodonta neglecta, Luticola } \\
\text { acidocinata, Navicula cariocincta, N. upsaliensis, } \\
\text { Nitzschia flexa, Parlibellus protractoides, } \\
\text { Stauroneis thermicola, Surirella brebissonii var. } \\
\text { brebissonii }\end{array}$ & $\begin{array}{l}\text { Amphipleura pellucida, Amphora cimbrica, } \\
\text { Caloneis lancettula, C. molaris, Cocconeis } \\
\text { disculus, Cymbella helvetica, C. lanceolata, } \\
\text { Fallacia subhamulata, Geissleria deccusis, } \\
\text { Luticola acidocinata, Navicula cariocincta, } \\
\text { N. oligotraphenta, N. oppugnata, N. upsaliensis, } \\
\text { Stauroneis thermicola, Surirella brebissonii var. } \\
\text { brebissonii }\end{array}$ \\
\hline
\end{tabular}


20\% [CEMAGREF 1982, Coste, Ayphassorho 1991, Kelly, Whitton 1995].

On the basis of the Red List of Algae for Polish species by Siemińska et al. [2006], various degrees of threat were distinguished (Ex - Extinct or probably extinct, $\mathrm{E}$ - Endangered, V - Vulnerable, R - Rare, I - Indeterminate).

\section{RESULTS}

The San River water was characterized by alkaline reaction (6.8-8.2) and moderate electrolyte content. High water quality (I water quality class) on the area of the San Valley Landscape Park was determined by chemical parameters (Table 1).

In total 353 diatom taxa were found at two sampling sites (293 taxa in Procisne and 272 in Sękowiec Village), among which eight taxa were considered as dominant. Achnathidium pyrenaicum (Hust.) Kobayasi and A. minutissimum (Kütz.) Czarnecki var. minutissimum were reached $50 \%$ of abundance in the assemblage, while the other dominant were developed less frequently $(5-10 \%)$ (Table 1, Plate 1).

Ecological preferences of diatom with respect to $\mathrm{pH}$ reaction, saprobity and trophy were presented according to Van Dam et al. [1994] list.

Based on $\mathrm{pH}$ reaction, two groups of diatom taxa were dominated in the San River - alkaliphilous and neutral (Figure 2). Based on saprobity, $\beta$-mesosaprobous (water quality class II) taxa was the most frequent. Oligosaprobous (class I and II) and $\alpha$-mesosaprobous (class III) taxa were also frequent (Figure 3). Oligotraphentic and mesotraphentic taxa were the most numerous in all sampling seasons (Figure 4).

All diatomaceous indices values (IPS, GDI, TDI) in the San River at both sampling sites were similar and indicated good, and high water quality (class II and I), what corresponded to good and high ecological status in all sampling seasons. A small share of taxa resistant to organic pollutants was also found (PT $=3.2-9.8 \%$ ) (Table 2).

Endangered and rare diatom taxa constituted about $10 \%$ of the total number of taxa. Seven diatom taxa were found in the category of endangered, eight in the category of vulnerable, and twentyfour in the category of rare (Table 1, Plate 2-3).

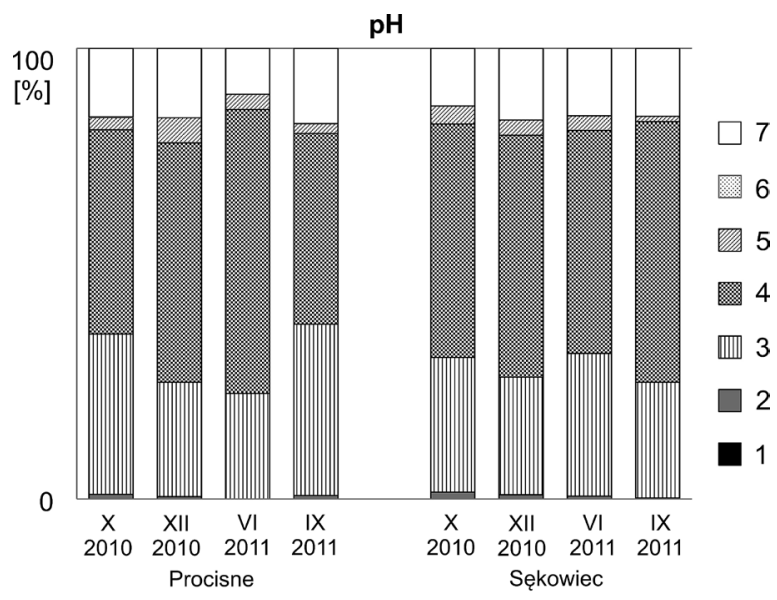

Figure 2. Percentage participation of diatoms at studied sites in the San River, according to Van Dam et al. [1994] classification system: $\mathrm{pH}$ range: 1 - acidobiontic, 2 acidophilous, 3 - neutral, 4 - alkaliphilous, 5 - alkalibiontic, 6 - indifferent, no apparent optimum, 7 - unknown

Table 2. The chemical parameter values measured in the San River in years 2010-2011 including Shannon-Wiener diversity index (H') and IPS, GDI and TDI indices

\begin{tabular}{|l|c|c|c|c|c|c|c|c|}
\hline Site & \multicolumn{4}{|c|}{ PROCISNE } & \multicolumn{4}{c|}{ SĘKOWIEC } \\
\hline Date & X.2010 & XII.2010 & VI.2011 & IX.2011 & X.2010 & XII.2010 & VI.2011 & IX.2011 \\
\hline pH & 7.3 & 6.9 & 7.2 & 8.2 & 7.3 & 7.1 & 7.3 & 8,0 \\
\hline Conductivity $[\mu \mathrm{S} / \mathrm{cm}]$ & 162 & 171 & 287 & 165 & 210 & 193 & 272 & 295 \\
\hline $\mathrm{Cl}-[\mathrm{mg} / \mathrm{l}]$ & - & - & - & 3.47 & - & - & - & 2.11 \\
\hline $\mathrm{NO}_{2}-\mathrm{N}[\mathrm{mg} / \mathrm{l}]$ & - & - & - & 0.27 & - & - & - & $<0.1$ \\
\hline $\mathrm{NO}_{3}-\mathrm{N}[\mathrm{mg} / \mathrm{l}]$ & - & - & - & 1.10 & - & - & - & 0.99 \\
\hline $\mathrm{SO}_{4}-\mathrm{S}[\mathrm{mg} /[]$ & - & - & - & 23.78 & - & - & - & 23.86 \\
\hline $\mathrm{H}^{\prime}$ & 4.92 & 5.82 & 4.37 & 5.28 & 5.59 & 5.60 & 4.22 & 4.34 \\
\hline IPS & 17.1 & 16.5 & 17.6 & 16.0 & 16.2 & 17.1 & 18.1 & 17.2 \\
\hline GDI & 15.5 & 15.2 & 16.3 & 14.8 & 14.7 & 15.2 & 16.2 & 15.7 \\
\hline TDI & 35.7 & 45.9 & 41.4 & 39.5 & 42.2 & 40.7 & 35.0 & 34.4 \\
\hline$\% \mathrm{PT}$ & 5.2 & 4.7 & 3.8 & 9.2 & 8.0 & 6.2 & 3.2 & 5.3 \\
\hline
\end{tabular}

\begin{tabular}{|l|l|}
\hline high & good \\
\hline & \\
\hline
\end{tabular}




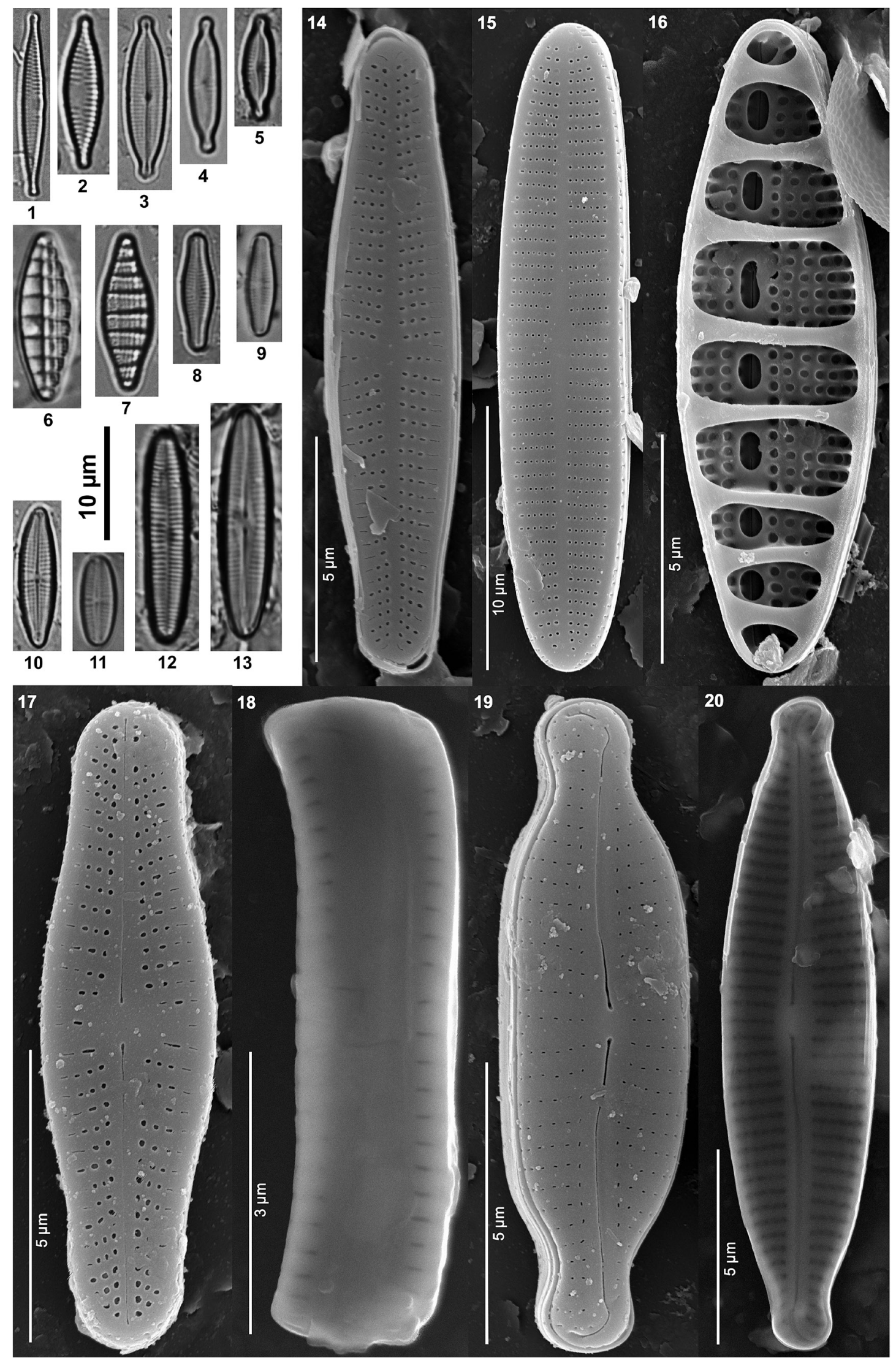

Plate I. Dominant taxa at studied sites

1-2 - Fragilaria perminuta (Grunow) Lange-Bert., 3, 20 - Encyonopsis subminuta Krammer \& Reichardt, 4-5, 19 - E. minuta Krammer \& Reichardt, 6-7, 16 - Denticula tenuis Kütz., 8, 17-18-Achnanthidium catenatum (Bily \& Marvan) Lange-Bert., 9, 14 - A. minutissimum (Kütz.) Czarnecki var. minutissimum, 10 - A. pyrenaicum (Hust.) Kobayasi, 11-13, 15 - A. subatomus (Hust.) Lange-Bert. 


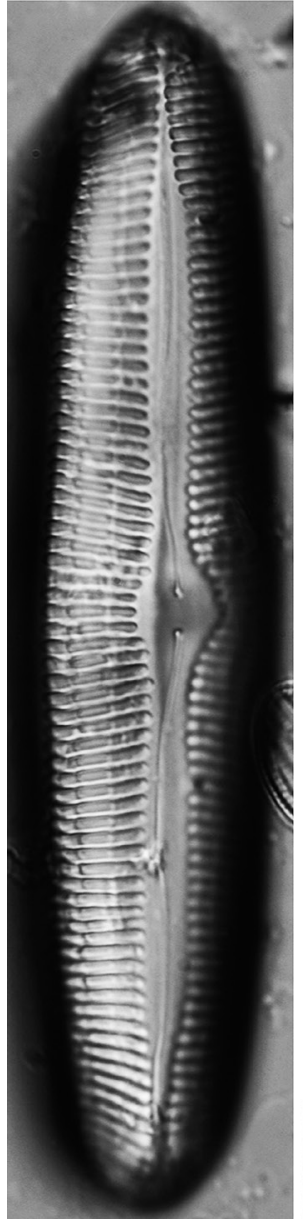

1

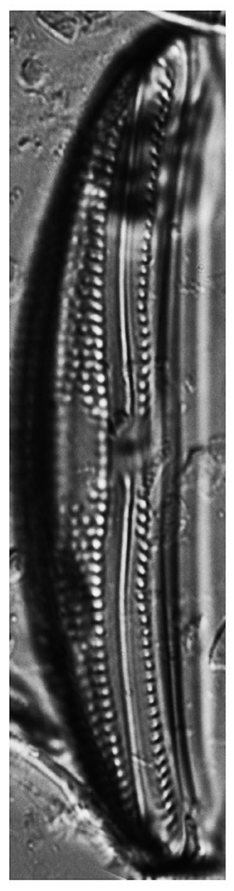

9
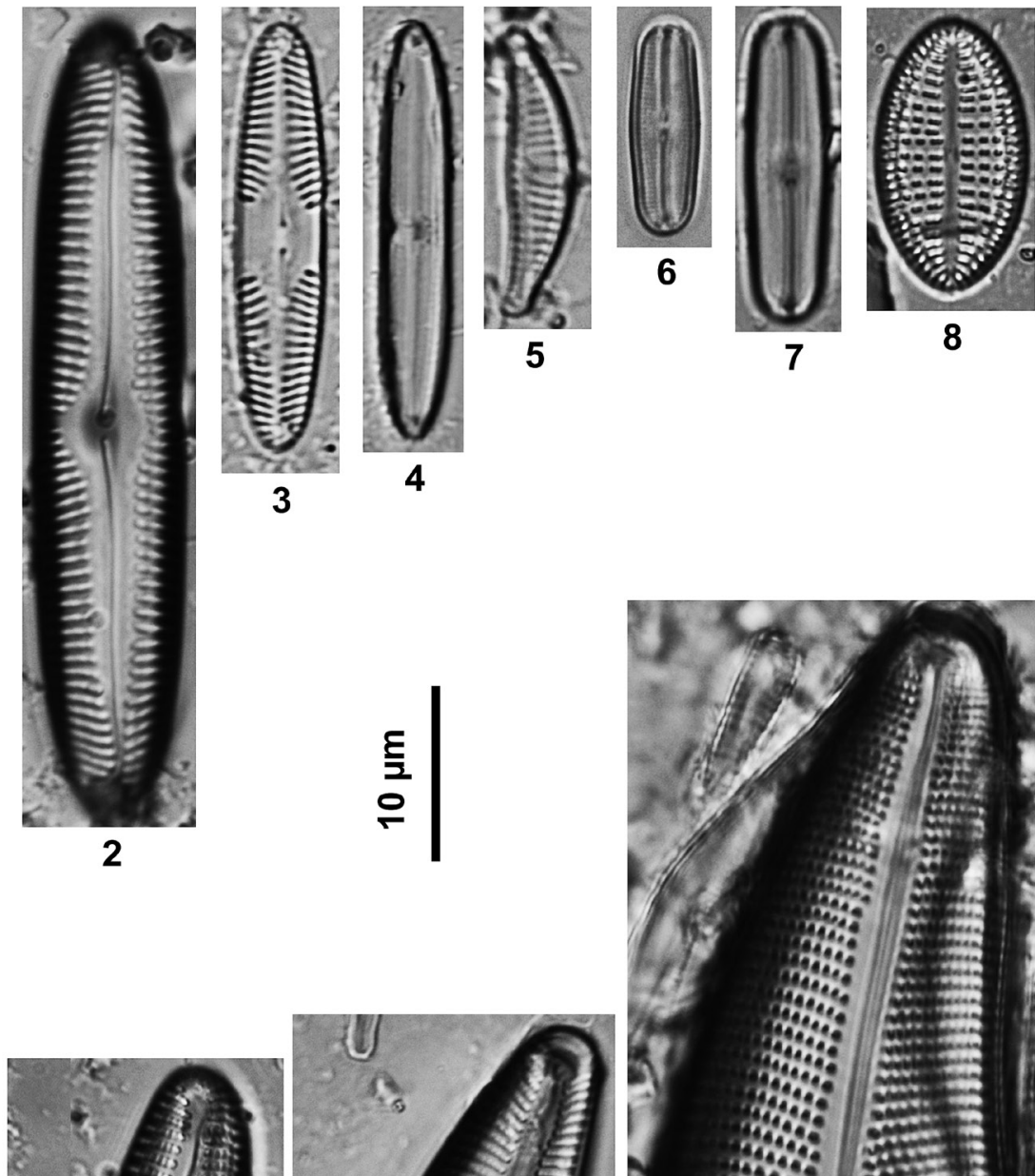

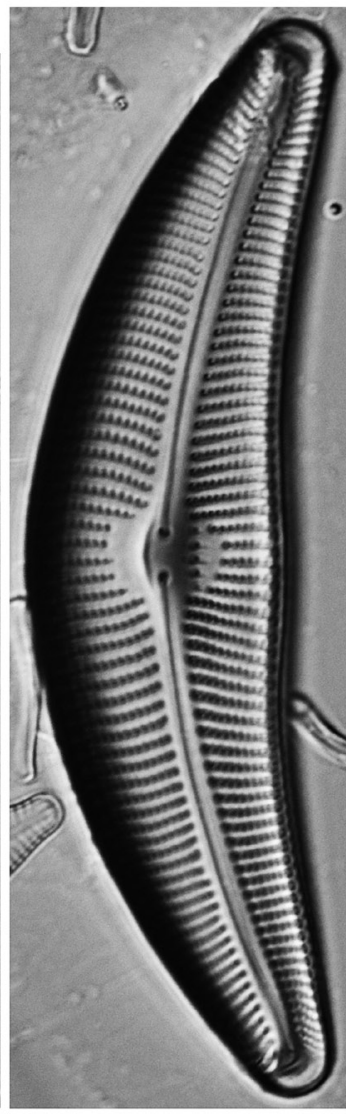

11

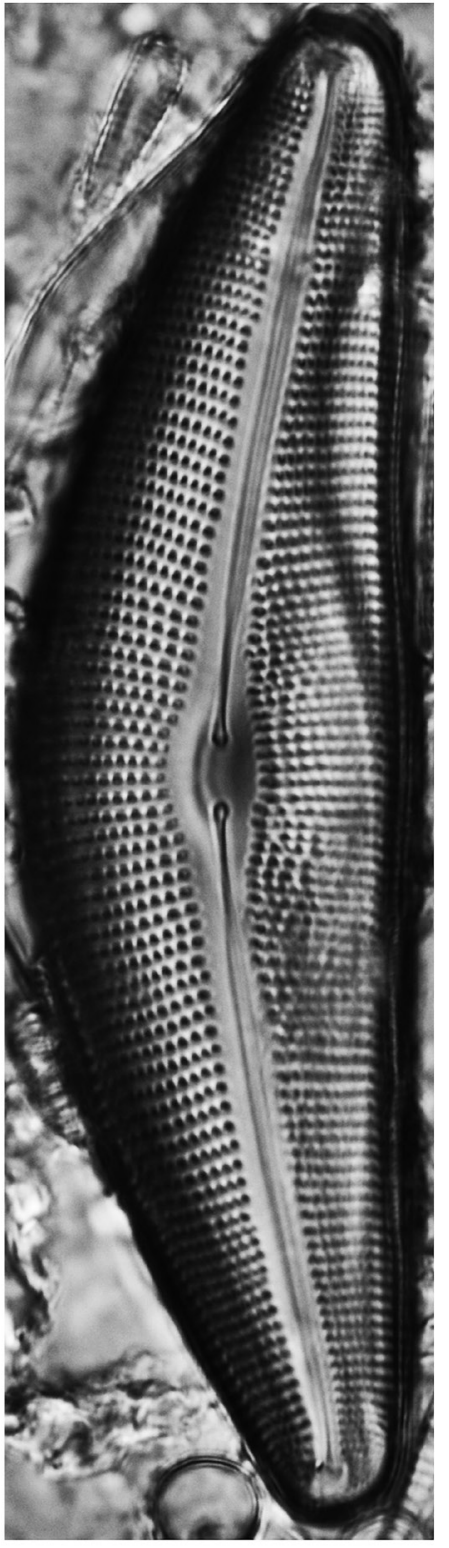

12

Plate II. Taxa from Red list of the algae in Poland (according to Siemińska et al. 2006)

1 - Pinnularia viridiformis Krammer, 2 - P. subrupestris Krammer, 3 - P. schoenfelderi Krammer, 4 - Neidium alpinum Hust., 5 - Encyonema ganemannii (Meister) Krammer, 6 - Fallacia lenzii (Hust.) Lange-Bert., 7 - F. subhamulata (Grunow) D.G. Mann, 8 - Cocconeis disculus (Schumann) Cleve, 9 - Amphora cimbrica Østrup, 10 - Cymbella helvetica Kütz., 11 - Cymbella proxima Reimer, 12 - Cymbella lanceolata (Agardh) Kirchner 


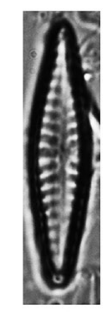

1

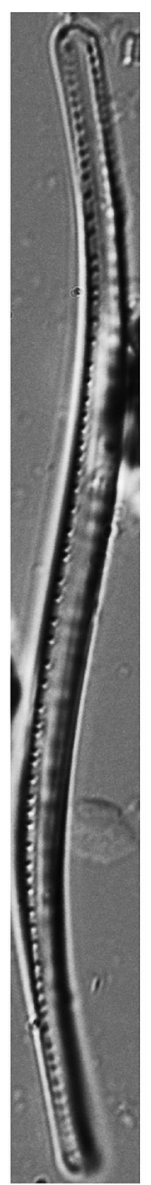

9

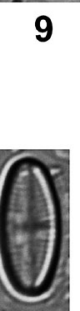

18
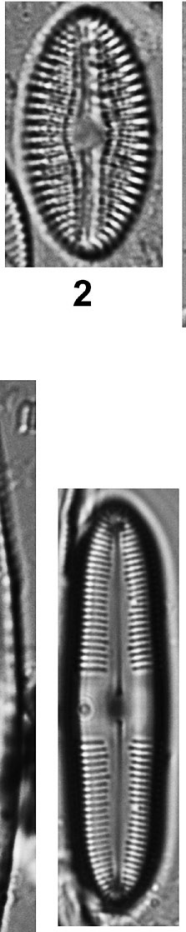

10

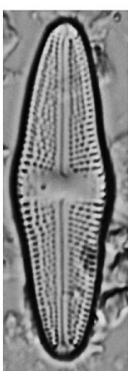

16

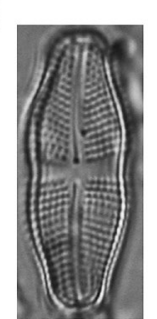

20

11

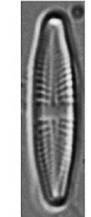

17
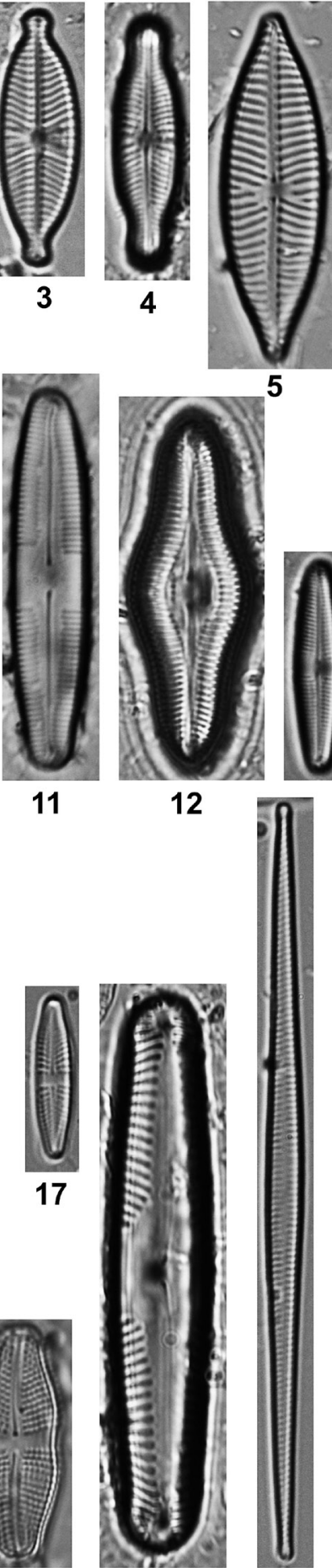

21

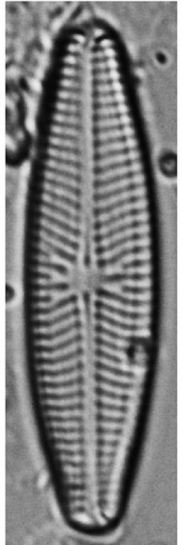

6

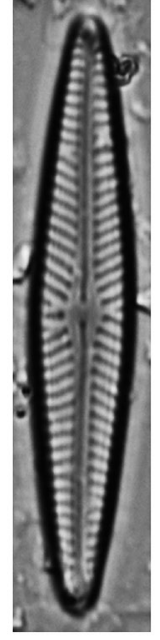

7

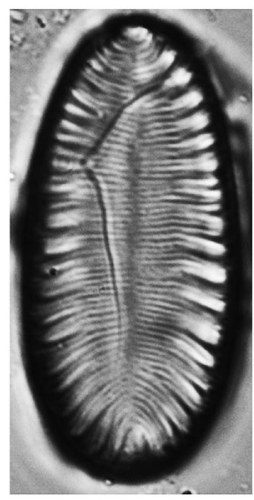

14

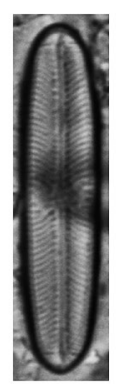

25

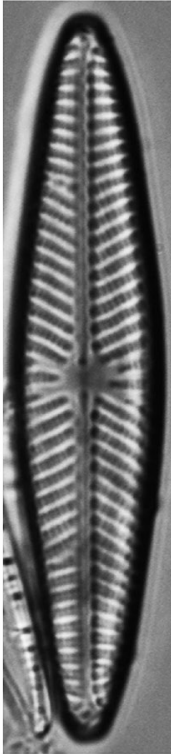

8
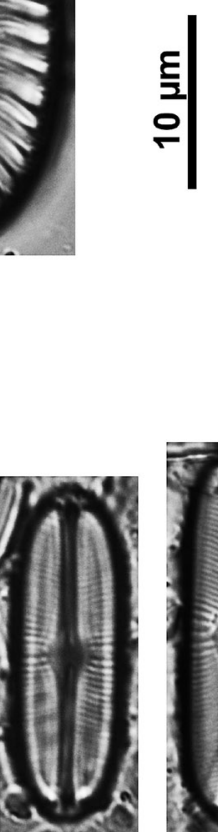

26

27

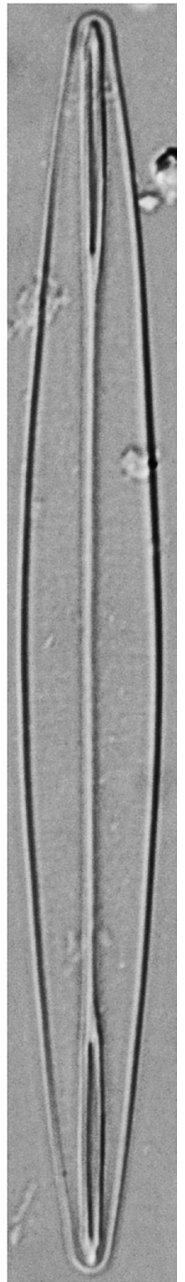

15

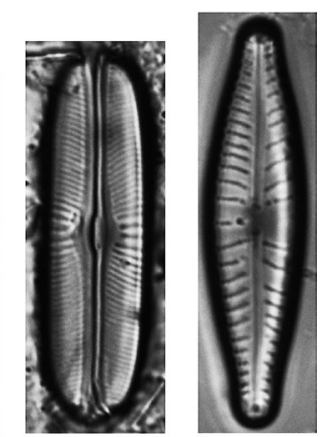

28

Plate III. Taxa from Red list of the algae in Poland (according to Siemińska et al. 2006)

1 - Hippodonta neglecta Lange-Bert., Metzeltin \& Witkowski, 2 - Diploneis pseudoovalis Hust., 3 - Geissleria deccusis (Østrup) Lange-Bert. \& Metzeltin, 4 - Parlibellus protractoides (Grunow) Witkowski, Lange-Bert. \& Metzeltin, 5 - Navicula upsaliensis (Grunow) Paragallo, 6 - N. splendicula Land, 7 - N. cariocincta Lange-Bert., 8 - N. oppugnata Hust., 9 - Nitzschia flexa Schumann, 10-11 - Caloneis molaris (Grunow) Krammer, 12 - C. schumaniana (Grunow) Cleve, 13 - C. lancettula (Schulz) Lange-Bert. \& Witkowski, 14 - Surirella brebissonii Krammer \& Lange-Bert. var. brebissonii, 15 - Amphipleura pellucida (Kütz.) Kütz., 16 - Luticola acidoclinata Lange-Bert., 17 - Stauroneis thermicola (Petersen) Lund, 18 - Psammothidium lauenburgianaum (Hust.) Bukhtiyarova \& Round, 19 - P. subatomoides (Hust.) Bukhtiyarova \& Round, 20 - Achnanthes coarctata (Bréb.) Grunow, 21 - Pinnularia microstauron (Ehrenb.) Cleve, 22 - Fragilaria tenera (W. Smith) Lange-Bert., $23-$ F. nanana Lange-Bert., 24 - F. brevistriata Grunow, 25 - Sellaphora pseudopupula (Krasske) Lange-Bert., 26-27 S. bacillum (Ehrenb.) D.G. Mann, 28 - Gomphonema sarcophagus Gregory 


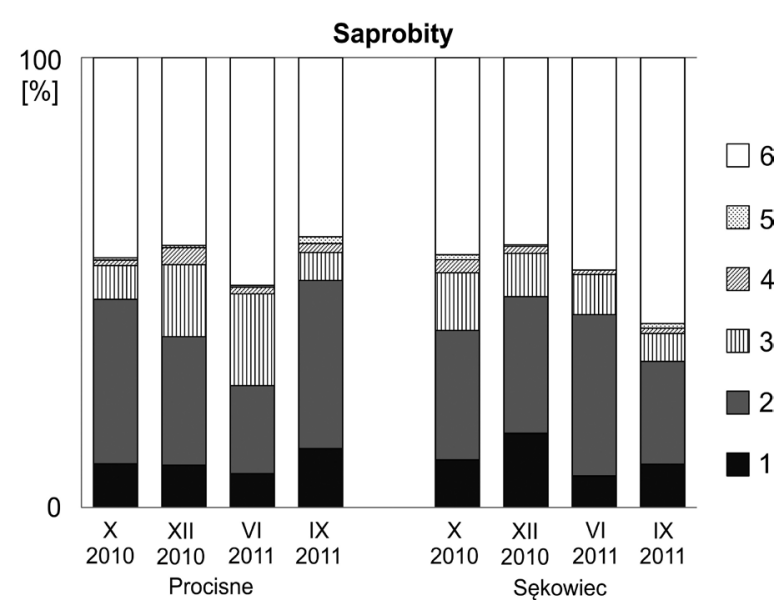

Figure 3. Percentage participation of diatoms at studied sites in the San River, according to Van Dam et al. [1994] classification system: saprobity range: 1 - oligosaprobous, 2 - $\beta$-mesosaprobous, 3 - $\alpha$-mesosaprobous, $4-\alpha$-meso-polysaprobous, 5 - polysaprobous, 6 - unknown

\section{DISCUSSION}

The spring areas of the San River are mountainous terrain of Bieszczady with sparse buildings for tourism and recreation. A significant percentage of the catchment area is covered by legal protection due to high natural and landscape values as in case of Bieszczady National Park and eight Landscape Parks, including the San Valley Lanscape Park. The San river has the highest quality of water in upper parts of its course. This is connected with the fact that source sections of the river flowing through the forest areas which are under inconsiderable influence of human pressure [WIOŚ 2004].

The water quality studies of the San River conducted in 2010-2011 in the area of the San Valley Landscape Park using benthic diatoms as bio-indicators indicated a good and very good water quality. This was confirmed by the chemical analysis, which classified waters of the San in Sękowiec and Procisne Villages in the first class of water quality. The waters of the San were characterized by very high species richness of diatoms - at two sites designated 353 taxa. Żelazna-Wieczorek [2012] gave a similar number of diatom species from the springs and the upper sections of streams which were tributaries of the San, but in the material collected from 17 positions. Other rivers and streams in the Podkarpacie region are also characterized by high species richness, but research on them was always conducted on a larger number of sites [Noga 2012, Pajączek et al. 2012, Noga et al. 2013a, c, d].

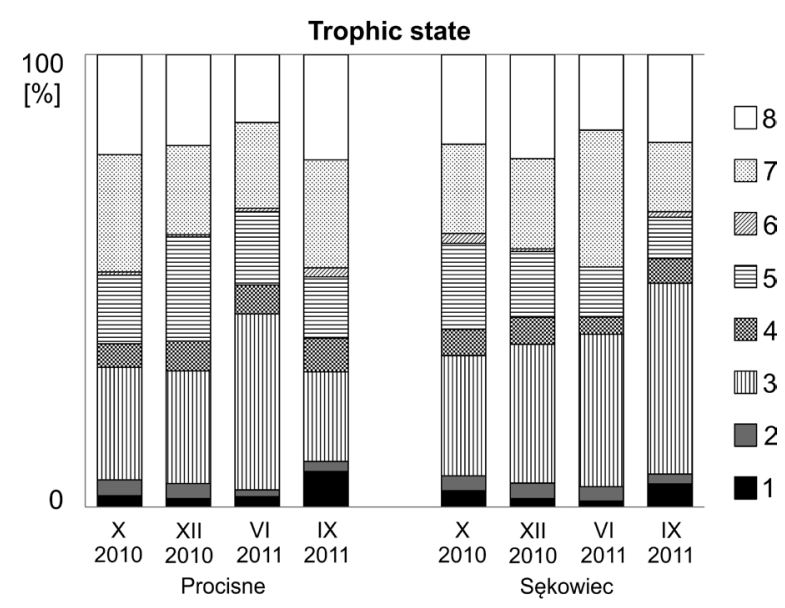

Figure 4. Percentage participation of diatoms at studied sites in the San River, according to Van Dam et al. [1994] classification system: trophic state: 1 - oligotraphentic, 2 - oligo-mesotraphentic, 3 - mesotraphentic, 4 - meso-eutraphentic, 5 - eutraphentic, 6 - hypereutraphentic, 7 - oligo- to eutraphentic, 8 - unknown

The most numerous were two species from the genus Achnanthidium in all study seasons. Numerous populations were created by A. pyrenaicum, especially on the site in Sękowiec (even> $50 \%$ share in assemblage). Optimum occurrence was in oligo- to mesotrophic water rich in calcium with medium to high content of electrolytes [Krammer, Lange-Bertalot 1991b]. According to Hofmann [1994], it was tolerant species, which prefer alkaline waters with $\mathrm{pH}>7$. It was very abundant in the territory of the Podkarpacie Province in upper course of Wisłok River [Noga 2012, Noga et al. 2013b). High pH values in the San River may be related to geological structure of terrain. All the Western and Eastern Carpathians, that is where the upper valley of the San is located, are composed of sedimentary rock such as sandstone, mudstone, marlston, conglomerates and shales that make up the so-called Carpathian flysch [Kondracki 2001, Sieradzki 2002]. Therefore Achnanthidium pyrenaicum may find here favorable conditions to grow.

The species that grow very abundantly on both study sites were also Achnanthidium minutissimum var. minutissimum, cosmopolitan species having a wide ecological spectrum. It occurs in a wide range of $\mathrm{pH}$ (4.3-9.2) in all types of water bodies with the conditions from oligo- to eutrophic. It is an indicator of water rich in oxygen. Numerous populations develop i.a. in high mountain streams [Krammer, Lange-Bertalot 1991b, Van Dam ety al. 1994, Hofmann et al. 2011, Kawecka 2012]. It is also one of the most 
common and most frequently noted diatoms in the Podkarpacie region especially in the upper courses of rivers and streams [Noga 2012, Pajączek et al. 2012, Noga et al. 2013a, b, c, d].

The alkaline character of water is reflected also in ecological preferences of the other species of diatoms developing in the San River. In all seasons, on both sites predominated alkalophiles $(\mathrm{pH}>7)$ and neutral $(\mathrm{pH}=7)$ taxa, as in most of the watercourses in Podkarpacie [Van Dam et al. 1994, Pajączek et al. 2012, Noga et al. 2013b,c].

Calculation on diatomaceous indices with the OMNIDIA software [Lecointe et al., 1993] showed that San River on the area of the San Valley Landscape Park carried waters of good quality. The IPS and GDI indices values reflecting the degree of organic and non-organic contaminants and trophic index TDI, indicated good or very good ecological status (second and first class of water quality). A small proportion $(>10 \%)$ of diatoms tolerant to organic pollution - \% PT was found on both sites, which is why it can be said that the San is not exposed to the risk of eutrophication [CEMAGREF 1982, Coste, Ayphassorho 1991, Kelly, Whitton 1995].

The study showed that the San River has the best ecological potential in relation to other studied watercourses of the Podkarpacie region [Noga et al. 2013a, b, c].

San River is the second largest watercourse in the south-eastern Poland. It is the main source of water supply in the Podkarpacie region. The studies carried out in the San Valley Landscape Park showed that the river is clean in the upper reaches with large diatom species richness with a high share of rare and endangered taxa. On both sites, in the four study seasons indicates 35 rare and endangered taxa [Siemińska et al. 2006], including 7 in the category of endangered (E): Encyonema gauemanni (Meister) Krammer, Fallacia lenzii (Hust.) Lange-Bert, Neidium alpinum Hust., Pinnularia subruperstris Krammer, $P$. schonfelderii Krammer, P. viridiformis Krammer, Sellaphora pseudopupula (Krasske) Lange-Bert were found on both sites, in the four study seasons. Therefore, further monitoring of these waters, especially in the spring areas is necessary.

\section{REFERENCES}

1. Bogaczewicz-Adamczak B., Kłosińska D., Zgrundo A. 2001. Diatoms as indicators of water pollution in the coastal zone of the Gulf of Gdańsk (southern Baltic Sea). Oceanol. Hydrobiol. St. 30(3-4), 59-75.

2. CEMAGREF 1982. Etude des méthodes biologiques quantitative d'appréciation de la qualité des eaux - Rapport Division Qualité des Eaux LyonAgence financiére de Bassin Rhone - Méditerranée - Corse, Pierre - Bénite. pp. 218.

3. Coste M., Ayphassorho H. 1991. Étude de la qualité des eaux du Bassin Artois-Picardie a l'aide des communautés de diatomées benthiques (Application des indices diatomiques) - Raport Cemagref. Bordeaux - Agence de l'Eau Artois-Picardie, Douai. pp. 277

4. Dumnicka E., Jelonek M., Kwandrans J., Wojtal A., Żurek R. 2006. Ichtiofauna i status ekologiczny wód Wisły, Raby, Dunajca i Wisłoki. Institute of Nature Conservation, Polish Academy of Sciences, Kraków, pp. 220.

5. Eloranta P. 1999. Application of diatom indices in Finnish Rivers. [In:] J. Prygiel, B.A. Whitton, J. Bukowska (eds), Use of Algae for Monitoring Rivers III. Agence de I' Eau Artois - Picardie, 138-144.

6. Hofmann G., Werum M., Lange-Bertalot H. 2011. Diatomeen im Süßwasser - Benthos von Mitteleuropa. Bestimmungsflora Kieselalgen für die ökologische Praxis. Über 700 der häufigsten Arten und ihre Ökologie. [In:] H. Lange-Bertalot (ed.). A.R.G. Gantner Verlag K.G. pp. 908.

7. Kawecka B. 2012. Diatom diversity in streams of the Tatra National Park (Poland) as indicator of environmental conditions. W. Szafer Institute of Botany, Polish Academy of Sciences, Kraków.

8. Kawecka B., Kwandrans J. 2000. Diversity of flora and fauna in running waters of the Province of Cracow (southern Poland) in relation to water guality. Acta Hydrobiol. 42(3/4), 145-173.

9. Kawecka B., Sanecki J. 2003. Didymosphenia geminata in running waters of southern Poland Symptoms of change in water quality? Hydrobiol. 495, 193-201.

10. Kawecka B., Kwandrans J., Szyjkowski A. 1999. Use of algae for monitoring rivers in Poland - Situation and development. [In:] J. Prygiel, B. A. Whitton, J. Bukowska (eds), Use of algae for monitoring rivers III. Agence de l'Eau Artois-Picardie, 57-65.

11. Kelly M.G. 2003. Short term dynamics of diatoms in an upland stream and implications for monitoring eutrophication. Environmental Pollution 125, 117-122.

12. Kelly M.G., Whitton B.A. 1995. The Trophic Diatom Index: a new index for monitoring eutrophication in rivers. J. Appl. Phycol. 7, 433-444.

13. Kelly M.G., Penny C.J., Whitton B.A. 1995. Comparative performance of benthic diatom indices used to assess river water quality. Hydrobiol. 302, 179-188.

14. Kelly M.G., Juggins S., Guthrie R., Pritchard S., Jamieson J., Rippey B., Hirst H., Yallop M. 2008. 
Assessment of ecological status in U.K. rivers using diatoms. Freshwater Biol. 53, 403-422.

15. Kondracki J. 2001. Geografia regionalna Polski. Państwowe Wydawnictwo Naukowe, Warszawa, pp. 441.

16. Krammer K. 2000. The genus Pinnularia. [In:] H. Lange-Bertalot (ed.). Diatoms of Europe. A.R.G. Ganter Verlag K.G., Vaduz 1, 1-703.

17. Krammer K. 2002. Cymbella. [In:] H. Lange-Bertalot (ed.). Diatoms of Europe. A.R.G., Gantner Verlag K.G., Rugell 3, 1-584.

18. Krammer K. 2003. Cymbopleura, Delicata, Navicymbula, Gomphocymbellopsis, Afrocymbella. [In:] H. Lange-Bertalot (ed.). Diatoms of Europe. A.R.G., Gantner Verlag K.G., Rugell 4, 1-530.

19. Krammer K., Lange-Bertalot H. 1986. Bacillariophyceae. 1. Naviculaceae. [In:] H. Ettl, J. Gerloff, H. Heyning \& D. Mollenhauer (eds). Süsswasserflora von Mitteleuropa. G. Fischer Verlag, Stuttgart - New York 2(1), 1-876.

20. Krammer K., Lange-Bertalot H. 1988. Bacillariophyceae. 2. Bacillariaceae, Epithemiaceae, Surirellaceae. [In:] H. Ettl, J. Gerloff, H. Heyning \& D. Mollenhauer (eds). Süsswasserflora von Mitteleuropa G. Fischer Verlag, Stuttgart - New York 2(2), 1-596.

21. Krammer K., Lange-Bertalot H. 1991a. Bacillariophyceae. 3. Centrales, Fragilariaceae, Eunotiaceae. [In:] H. Ettl, J. Gerloff, H. Heyning \& D. Mollenhauer (eds). Süsswasserflora von Mitteleuropa. G. Fischer Verlag, Stuttgart - Jena 2(3), 1-576.

22. Krammer K., Lange-Bertalot H. 1991b. Bacillariophyceae. 4. Achnanthaceae, Kritische Ergänzungen zu Navicula (Lineolate) und Gomphonema, Gesamtliteraturverzeichnis. [In:] H. Ettl, J. Gerloff, H. Heyning \& D. Mollenhauer (eds). Süsswasserflora von Mitteleuropa. G. Fischer Verlag, Stuttgart - Jena 2(4), 1-437.

23. Kukuła K. 2002. Dorzecze Górnego Sanu i jego walory. [In:] F. Oberc (ed.), Zeszyty Archiwum Ziemi Sanockiej. Fundacja „Archiwum Ziemi Sanockiej”, Sanok - Zahutyń 2, 30-35.

24. Kwandrans J., Eloranta P., Kawecka B., Wojtan K. 1999. Use of benthic diatom communities to evaluate water quality in rivers of southern Poland. [In:] J. Prygiel, B.A. Whitton, J. Bukowska (eds). Use of algae for monitoring rivers III. Agence de l'Eau Artois-Picardie, 154-156.

25. Kwandrans J. 2002. Upper Vistula River: Response of aquatic communities on pollution and impoundment. IX. Benthic diatom communities. Polish J. Ecol. 50(2), 223-236.

26. Lecointe C., Coste M., Prygiel J. 1993. OMNIDIA: software for taxonomy, calculation of diatom indices and inventories management. Hydrobiol. 269/270, 509-513.
27. Noga T. 2012. Diversity of diatom communities in the Wisłok River (SE Poland). [In:] K. Wołowski, I. Kaczmarska, J. M. Ehrman \& A. Z. Wojtal (eds), Phycological Reports: Current advances in algal taxonomy and its applications: phylogenetic, ecological and applied perspective. Institute of Botany Polish Academy of Sciences, Krakow, 109-128.

28. Noga T., Siry K. 2010. Różnorodność flory okrzemek w potoku Łubienka (Pogórze Dynowskie, Polska SE). Zeszyty naukowe PTIE i PTG 12, 75-86.

29. Noga T., Stanek-Tarkowska J., Peszek Ł., Pajączek A., Kowalska S. 2013a. Use of diatoms to assess water quality of anthropogenically modified Matysówka stream. Journal of Ecological Engineering 14(2), 1-11.

30. Noga T., Stanek-Tarkowska J., Pajączek A., Peszek Ł., Kochman N. 2013b. Ecological characterization of diatom communities in the Wisłok River with application of their indicatory role to the evaluation of water quality. Journal of Ecological Engineering 14(4), 18-27.

31. Noga T., Stanek-Tarkowska J., Pajączek A., Peszek Ł., Kochman N., Woźniak K. 2013c. Application of diatoms to assess the quality of the waters of the Baryczka stream, left-side tributary of the River San. Journal of Ecological Engineering 14(2), 8-23.

32. Noga T., Stanek-Tarkowska J., Pajączek A., Peszek Ł., Kochman N., Kozak E., Kędziora Ł., Wąsacz P. 2013d. Wstępne rozpoznanie okrzemek Bacillariophyceae Jeziorek Duszatyńskich (Bieszczady Zachodnie). Roczniki Bieszczadzkie 21, 127-146.

33. Pajączek A., Musiałek M., Pelczar J. \& Noga T. 2012. Diversity of diatoms in the Mleczka River, Morwawa River and Różanka Stream (tributaries of the Wisłok River, SE Poland), with particular reference to threatened species. [In:] K. Wołowski, I. Kaczmarska, J. M. Ehrman \& A. Z. Wojtal (eds), Phycological Reports: Current advances in algal taxonomy and its applications: phylogenetic, ecological and applied perspective. Institute of Botany Polish Academy of Sciences, Krakow, 129-152.

34. Prygiel J. 2002. Mangement of the diatom monitoring network in France. J. Appl. Phycol.14, 19-26.

35. Prygiel J., Coste M. 1993. The assessment of water quality in the Artois-Picardie water basin (France) by the use of diatom indices. Hydrobiol., 269/270, 343-349.

36. Rakowska B. 2001. Studium różnorodności okrzemek ekosystemów wodnych Polski niżowej. Wydawnictwo Uniwersytetu Łódzkiego, Łódź.

37. Rakowska B., Szczepocka E. 2011. Demonstration of the Bzura River restoration using diatom indices. Biologia 66(3), 411-417.

38. Siemińska J. 1964. Bacillariophyceae - Okrzemki, [In:] K. Starmach (ed.), Flora słodkowodna Polski, 6. PWN, Warszawa. 
39. Siemińska J., Bąk M., Dziedzic J., Gąbka M., Gregorowicz P., Mrozińska T., Pełechaty M., Owsiany P. M., Pliński M., Witkowski A. 2006. Red list of the algae in Poland. [In:] Z. Mirek, K. Zarzycki, W. Wojewoda, Z. Szeląg (eds). Red list of plants and fungi in Poland W. Szafer Institute of Botany, Polish Academy of Sciences, Kraków, 37-52.

40. Sieradzki S. Geologia Doliny Sanu. [In:] F. Oberc (ed.), Zeszyty Archiwum Ziemi Sanockiej. Fundacja „Archiwum Ziemi Sanockiej”, Sanok Zahutyń 2, 30-35.

41. Szczepocka E., Szulc B. 2009. The use of benthic diatoms in estimating water quality of variously polluted rivers. Oceanol. Hydrobiol. St. 38(1), 17-26.

42. Szlak wodny „Błękitny San” - przewodnik. 2005. Podkarpacka Regionalna Organizacja Turystyczna, Rzeszów.

43. Tambor A., Noga T. 2011. Różnorodność flory okrzemek w rzece Lubcza i potoku Lubenia
(Podgórze Rzeszowskie, Polska SE). Rocznik Przemyski 47(3), 105-118.

44. Van Dam H., Martens A., Sinkeldam J. 1994. A coded checklist and ecological indicator values of freshwater diatoms from the Netherlands. Netherlands J. Aquatic Ecol. 28, 117-133.

45. WIOŚ Rzeszów. 2004. Raport o stanie środowiska w Województwie Podkarpackim (The state of the environment, report in Subcarphatian Voivodeship).

46. Żelazna-Wieczorek J. 2012. Okrzemki Bacillariophyta źródeł i odcinków źródłowych potoków w górnym odcinku rzeki San. Roczniki Bieszczadzkie 20, 220-229.

47. Żelazowski E., Magiera M., Kawecka B., Kwandrans J., Kotowicz J. 2004. Use of algae for monitoring rivers in Poland - in the light of a new law for environmental protection. Oceanol. Hydrobiol. St. 33(4), 27-39. 